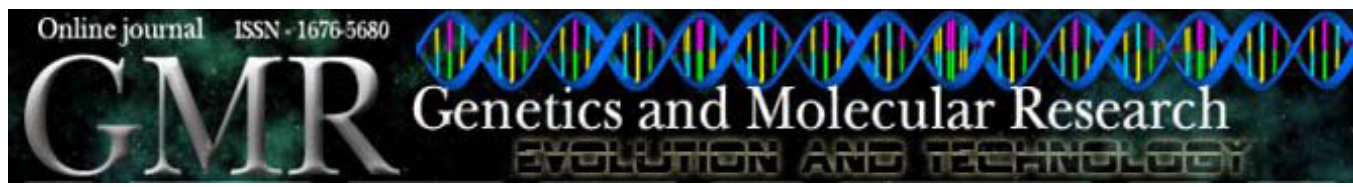

\title{
Isolation of retro-transcribed RNA from in vitro Mycosphaerella fijiensis-infected banana leaves
}

C.M. Rodríguez-García ${ }^{1}$, L. Peraza-Echeverría ${ }^{1}$, I.R. Islas-Flores ${ }^{2}$, B.B. Canto-Canché ${ }^{1}$ and R. Grijalva-Arango ${ }^{1}$

${ }^{1}$ Unidad de Biotecnología, Centro de Investigación Científica de Yucatán, Colonia Chuburná de Hidalgo, Mérida, Yucatán, México

${ }^{2}$ Unidad de Bioquímica y Biología Molecular de Plantas, Centro de Investigación Científica de Yucatán, Colonia Chuburná de Hidalgo, Mérida, Yucatán, México

Corresponding author: C.M. Rodríguez-García

E-mail: koyi@cicy.mx

Genet. Mol. Res. 9 (3): 1460-1468 (2010)

Received April 20, 2010

Accepted May 21, 2010

Published July 27, 2010

DOI 10.4238/vol9-3gmr865

ABSTRACT. High polyphenol and polysaccharide levels in plant
tissues such as banana fruit and leaves constitute a significant challenge
to the extraction of sufficient amounts of high-quality RNA required
for cDNA library synthesis and molecular analysis. To determine their
comparative effectiveness at eliminating polyphenols, polysaccharides
and proteins, three protocols for RNA extraction from in vitro banana
plantlet leaves were tested: Concert ${ }^{\mathrm{TM}}$ Plant RNA isolation kit, a small-
scale protocol based on Valderrama-Cháirez, and a modified version
of the Valderrama-Cháirez protocol. RNA quantity and purity were
evaluated by UV-spectrophotometry using DEPC-treated water and Tris-
HCl, pH 7.5. Purity was greater using Tris-HCl. The Concert ${ }^{\mathrm{TM}}$ Plant
protocol produced the poorest quality RNA. Reverse transcription into
cDNAs from RNA isolated from in vitro banana plantlet leaves infected
with Mycosphaerella fijiensis using the modified Valderrama-Cháirez
protocol, followed by PCR using primers designed against $\gamma$-actin from
banana and $M$. fijiensis, yielded products of the anticipated size. In
addition, this protocol reduced the processing time, lowered costs, used 
less expensive equipment, and could be used for other plants that have the same problems with high polyphenol and polysaccharide levels.

Key words: Banana; Mycosphaerella fijiensis; Polyphenols; Polysaccharides; RNA isolation; Black leaf streak disease

\section{INTRODUCTION}

The isolation of large amounts of high-quality RNA from plant tissues rich in polysaccharides and polyphenols, including tannins, pigments and other metabolites, requires an efficient method. Several technical protocols have been described for RNA extraction from these plant tissue types (Louime et al., 2008; Montenegro et al., 2008; Suzuki et al., 2008; Wang et al., 2008; Vasanthaiah et al., 2008), and biotechnology companies have developed kits or protocols suitable for particular cells, organs or tissues. However, an efficient protocol specifically for recalcitrant plant tissues does not yet exist, meaning that successful protocols must be adapted or developed through the modification of existing methods, while considering the particular features of the target plant material (MacRae, 2007).

Banana (Musa spp) is cultivated in tropical and subtropical regions worldwide, and its fruit represents an important carbohydrate resource in developing countries. Like most other commercial crops, banana is affected by pathogens, the most important being the fungus Mycosphaerella fijiensis Morelet, responsible for black Sigatoka or black leaf streak disease, a major threat to banana crops worldwide. In molecular studies of banana- $M$. fijiensis interaction, the isolation of large amounts of high-quality RNA is crucial for cDNA library construction. Although protocols for RNA extraction from banana fruit (peel and pulp) (Manrique-Trujillo et al., 2007; Mbéguié-A-Mbéguié et al., 2007; Xu et al., 2007), root (Van den Berg et al., 2004) and greenhouse leaves (Sánchez-Rodríguez et al., 2008) have been described, there is currently no available efficient method for the isolation of large amounts of high-quality RNA from in vitro $M$. fijiensis-inoculated banana leaves that produces RNA suitable for cDNA library preparation. Our research required the isolation of high-quality RNA from in vitro banana plantlet leaves, which has proved to be an ongoing challenge. Initially, we compared the Trizol ${ }^{\circledR}$ reagent and CTAB or SDS-containing protocols, also we tested the method reported by Rodrigues et al. (2007), but even after repeated adjustments, these produced low yields or poor-quality RNA (data not shown). We then tested three protocols commonly used to eliminate polyphenols, polysaccharides and proteins: Concert ${ }^{\mathrm{TM}}$ Plant RNA Reagent, a commercially available total RNA extraction kit appropriate for eliminating these metabolites from plant tissues; a small-scale protocol developed to extract RNA from cactus fruit rich in polysaccharides (Valderrama-Cháirez et al., 2002), which has been successfully applied with Tagetes erecta (Paredes-López et al., 2007) and prickly pear (Rosas-Cárdenas et al., 2007), and a modified version of this protocol. Quality and quantity of the RNA isolated from banana were assessed by UV-spectrophotometric analysis either in DEPC-treated water or Tris- $\mathrm{HCl}$ buffer, $\mathrm{pH} 7.5$; electrophoresis on TAE-agarose gels, reverse transcription into cDNAs and subsequent polymerase chain reaction (PCR) amplification using primers designed to specifically amplify $\gamma$-actin from cDNAs of banana and $M$. fijiensis. The modified protocol efficiently removed polyphenols, polysaccharides and proteins from in vitro banana plantlet leaves and yielded high-quality RNA in sufficient quantities for cDNA preparation. 


\section{MATERIAL AND METHODS}

\section{Fungal material}

Mycosphaerella fijiensis conidia, strain C1N3H2 (accession No. 389280 IMI), were harvested following an in vitro conidium production protocol (Peraza-Echeverría et al., 2008). Briefly, $100 \mathrm{~mL} / \mathrm{L} \mathrm{V}^{\circledR}$ juice was added to $0.2 \mathrm{~g} / \mathrm{L} \mathrm{CaCO}_{3}$ and $20 \mathrm{mg} / \mathrm{L}$ microbiological agar, autoclaved and placed on Petri dishes. Individual dishes were inoculated with $2 \mathrm{~mL}$ mycelium solution ( $1 \mathrm{~g}$ mycelium macerated with $5 \mathrm{~mL}$ sterile water) and left to grow at $20 \pm 2^{\circ} \mathrm{C}$ under continuous, cool-white fluorescent and black light. After seven days, conidia from each Petri dish were harvested with $2.4 \mathrm{~mL} \mathrm{1 \%}$ gelatin $(\mathrm{w} / \mathrm{v})$, filtered through 2 pieces of fine cheesecloth and collected in a $50-\mathrm{mL}$ Falcon tube. A suspension containing 200 conidia/ $\mu \mathrm{L}$ was spread with a camel hair brush onto the abaxial portion of in vitro banana leaves.

\section{Plant material}

Banana leaves (Musa acuminata, subgroup Cavendish Grand-Nain) were collected from 3-month-old in vitro plants grown on MS solid culture medium containing $30 \mathrm{~g} / \mathrm{L}$ sucrose and $2 \mathrm{~g} / \mathrm{L}$ gelling agent (Gelrite, Sigma) performed at $28 \pm 2^{\circ} \mathrm{C}$ under $50 \mu \mathrm{mol} \cdot \mathrm{m}^{-2} \cdot \mathrm{s}^{-1}$ in a $16-\mathrm{h}$ light/8-h dark photoperiod. The leaves were weighed, immediately submerged in liquid nitrogen and stored at $-80^{\circ} \mathrm{C}$ until use. For RT-PCR analysis, in vitro banana plantlet leaves were artificially inoculated with $M$. fijiensis conidia and leaf samples taken 15 days post-inoculation.

The sterile distilled water used to prepare solutions and buffers and to dissolve RNA was treated with $0.1 \%(\mathrm{v} / \mathrm{v})$ diethyl pyrocarbonate (DEPC; Sigma). All tips, tubes, and DEPCtreated water were autoclaved twice at $121.1^{\circ} \mathrm{C}$ for $20 \mathrm{~min}$. Mortars, pestles and spatulas were washed with distilled water containing $3 \%(\mathrm{w} / \mathrm{v}) \mathrm{NaOCl}$, rinsed with sterile distilled water and autoclaved at $121.1^{\circ} \mathrm{C}$ for $20 \mathrm{~min}$ (twice).

\section{Concert $^{\text {TM }}$ Plant RNA Reagent (C protocol)}

Freshly harvested in vitro banana leaves $(0.5 \mathrm{~g})$ were frozen with liquid $\mathrm{N}_{2}$ and powdered in a mortar and a pestle. Small portions of powder were added to a vial containing $2.5 \mathrm{~mL}$ cold $\left(4^{\circ} \mathrm{C}\right)$ Plant RNA Reagent, and the contents were mixed briefly with a micropipette and divided into 4 tubes $(0.625 \mathrm{~mL})$. Each tube was agitated briefly to completely resuspend the sample, incubated for $5 \mathrm{~min}$ at room temperature and centrifuged at $12,000 \mathrm{~g}$ for $2 \mathrm{~min}$. The supernatants were transferred to RNAse-free tubes along with $125 \mu \mathrm{L} 5 \mathrm{M} \mathrm{NaCl}$, which were vortexed. After mixing, $375 \mu \mathrm{L}$ chloroform was added; the suspension was completely mixed by inversion and centrifuged at $12,000 \mathrm{~g}$ for $10 \mathrm{~min}$ at $4^{\circ} \mathrm{C}$ to separate the phases. The aqueous phase was transferred to RNase-free tubes. RNA was precipitated by adding an equal volume of isopropyl alcohol and mixing, and after $10 \mathrm{~min}$ at room temperature, RNA was centrifuged at $12,000 \mathrm{~g}$ for $10 \mathrm{~min}$ at $4{ }^{\circ} \mathrm{C}$. The supernatants were decanted to recover the pellets, $1 \mathrm{~mL} \mathrm{75 \%} \mathrm{ethanol} \mathrm{was} \mathrm{added,} \mathrm{and} \mathrm{the}$ suspension was centrifuged at $12,000 \mathrm{~g}$ for $1 \mathrm{~min}$ at room temperature. The supernatants were decanted carefully and the tubes briefly centrifuged to remove any residual liquid. The pellet (RNA) in each tube was dissolved in $10 \mu \mathrm{L}$ DEPC-treated water. The suspen- 
sions were pooled in a new tube and analyzed in a spectrophotometer. The RNA was stored at $-80^{\circ} \mathrm{C}$ until use.

\section{Small-scale Valderrama-Cháirez et al. protocol (VC protocol)}

Fresh in vitro banana leaves $(0.5 \mathrm{~g})$ were frozen with liquid $\mathrm{N}_{2}$ and powdered for 5 min using a mortar and a pestle previously chilled to $-20^{\circ} \mathrm{C}$ with liquid $\mathrm{N}_{2}$ added continuously. Small portions of powdered sample were added to a vial containing $3 \mathrm{~mL}$ extraction buffer (150 mM Tris base (hydroxymethyl-hydrochloride), 2\% (w/v) SDS, $100 \mathrm{mM}$ EDTA, adjusted to $\mathrm{pH} 7.5$ with saturated boric acid), and $30 \mu \mathrm{L} \beta$-mercaptoethanol $(1 \%$, v/v) added just before use. This suspension was quickly mixed using a cut tip to avoid RNA damage, transferred to Eppendorf tubes ( $750 \mu \mathrm{L}$ per tube), precipitated with $66 \mu \mathrm{L} 5 \mathrm{mM}$ potassium acetate, and $150 \mu \mathrm{L}$ absolute ethanol, and vortexed for $1 \mathrm{~min}$. Next, $850 \mu \mathrm{L}$ chloroformisoamyl alcohol $(49: 1, \mathrm{v} / \mathrm{v})$ was added, and the suspension vortexed for $10 \mathrm{~s}$ and centrifuged at $16,000 \mathrm{~g}$ for $20 \mathrm{~min}$ at room temperature. The supernatants were recovered and transferred to new tubes, $850 \mu \mathrm{L}$ phenol-chloroform-isoamyl alcohol $(25: 24: 1, \mathrm{v} / \mathrm{v} / \mathrm{v})$ was added per tube, and the tubes were vortexed for $10 \mathrm{~s}$ and centrifuged at $16,000 \mathrm{~g}$ for $15 \mathrm{~min}$ at room temperature. The supernatants were recovered and transferred to new tubes, along with 850 $\mu \mathrm{L}$ chloroform-isoamyl alcohol. The tubes were vortexed for $10 \mathrm{~s}$ and centrifuged at 16,000 $g$ for $15 \mathrm{~min}$ at $4{ }^{\circ} \mathrm{C}$. The supernatants were recovered, $12 \mathrm{M} \mathrm{LiCl}$ was added to a final concentration of $3 \mathrm{M}$, and the tubes were gently mixed by inversion and left to stand overnight at $-20^{\circ} \mathrm{C}$. The samples were then centrifuged at $16,000 \mathrm{~g}$ for $20 \mathrm{~min}$ at $4{ }^{\circ} \mathrm{C}$, and the pellets were washed twice with $70 \%$ ethanol $(500 \mu \mathrm{L}$ each) and centrifuged again at $16,000 \mathrm{~g}$ for $10 \mathrm{~min}$ at $4^{\circ} \mathrm{C}$. The pellets were dried at room temperature and resuspended in $10 \mu \mathrm{L}$ DEPC-treated sterile distilled water. The suspensions were pooled in a new tube, and RNA quantified in a UV-light spectrophotometer. RNA was stored at $-80^{\circ} \mathrm{C}$ until use.

\section{Modified small-scale Valderrama-Cháirez et al. protocol (MVC protocol)}

This was carried out as described above for the VC protocol, but with some modifications: $4 \%(\mathrm{w} / \mathrm{v})$ SDS and $2 \%(\mathrm{v} / \mathrm{v}) \beta$-mercaptoethanol, and the addition of $3 \%(\mathrm{w} / \mathrm{v})$ PVP-40 in the extraction buffer $(3 \mathrm{~mL})$, where the last two reagents were added just before use. An additional step was added, the incubation of the homogenate (material powdered with modified extraction buffer) at $65^{\circ} \mathrm{C}$ for $10 \mathrm{~min}$. After allowing the samples to return to room temperature, potassium acetate and absolute ethanol were then added.

\section{Total RNA analysis}

RNA quantity and quality (purity and integrity) were determined using spectrophotometry at $260 \mathrm{~nm}$, and $\mathrm{A}_{260 / 210}, \mathrm{~A}_{260 / 230}$ and $\mathrm{A}_{260 / 280}$ absorbance ratios, as well as by visual analysis on gels. Given that the $\mathrm{A}_{260 / 20}$ ratio is considerably influenced by the $\mathrm{pH}$ of the solution in which it is diluted for measurement (Wilfinger, 1997; Okamoto and Okabe, 2000), the samples were diluted (1:100) in $10 \mathrm{mM}$ Tris-HCl, $\mathrm{pH} 7.5$, or in DEPC-treated sterile distilled water before comparison of their absorbance values. For analysis by gel electrophoresis, $2 \mu \mathrm{g}$ RNA samples were mixed with $17 \mu \mathrm{L}$ denaturing solution [641 $\mu \mathrm{L} 2.77 \mathrm{M}$ formamide (Sigma- 
Aldrich); $128.2 \mu \mathrm{L}$ 3-[N-morpholine] propanesulfonic acid (Sigma-Aldrich) (MOPS) 10X buffer, $\mathrm{pH}$ 7, and 230.8 $\mu \mathrm{L} 12.3 \mathrm{M}$ formaldehyde (Sigma-Aldrich); final volume $=1 \mathrm{~mL}]$. The samples were then incubated for $5 \mathrm{~min}$ at $65^{\circ} \mathrm{C}$, immediately chilled on ice for $5 \mathrm{~min}$, and $2 \mu \mathrm{L}$ loading buffer [50\% glycerol, $1 \mathrm{mM}$ EDTA, $10 \mu \mathrm{L}$ ethidium bromide $(10 \mathrm{mg} / \mathrm{mL})$ and $0.025 \%$ bromophenol blue; final volume $=1 \mathrm{~mL}]$ was added. Samples $(25 \mu \mathrm{L})$ were loaded onto $1.2 \%$ agarose gels in 1X TAE buffer following Masek et al. (2005) and run at $70 \mathrm{~V}$ for $40 \mathrm{~min}$.

Three replicates were done for all experiments. All statistical analyses were done with the STATGRAPHICS Plus version 4.1 software package (Manugistics, Rockville, USA).

\section{Retro-transcribed RNA analysis}

RNA performance in generating cDNA was tested by first treating $1 \mu \mathrm{g}$ RNA sample with 1 unit DNase following manufacturer instructions (Invitrogen). RNA $(0.5 \mu \mathrm{g})$ was used to synthesize the first cDNA strand by applying Superscript III reverse transcriptase following manufacturer instructions (Invitrogen). The cDNA was analyzed by amplification of $\gamma$-actin genes from the host and the pathogen. In PCR, $2 \mu \mathrm{L}$ cDNA was used as a template, and $M$. fijiensis and M. acuminata genomic DNA (1 ng) samples were used as positive controls. Reaction primers were specifically designed for cDNAs from $M$. fijiensis: $\gamma$-actin forward primer (5'-CTTGACTCCGGTGACGGTGTCACTC-3') and $\gamma$-actin reverse primer (5'-CGTCAGG AAGCTCGTAGGACTTCTC-3'), and Musa acuminata: $\gamma$-actin forward primer (5'-CTGGT GATGGTGTGAGCCACACTGTTC-3') and $\gamma$-actin reverse primer (5'-CACTGAGAACGA TGTTGCCATACAGGTC-3'). Conditions for PCR were: $95^{\circ} \mathrm{C}$ for $5 \mathrm{~min} ; 36$ cycles of $94^{\circ} \mathrm{C}$ for $30 \mathrm{~s}, 65^{\circ} \mathrm{C}$ for $30 \mathrm{~s}, 72^{\circ} \mathrm{C}$ for $1 \mathrm{~min}$, and $72^{\circ} \mathrm{C}$ for $7 \mathrm{~min}$. Denaturing gel electrophoresis was not used, only the products amplified were denatured, avoiding the use of highly toxic formaldehyde in $1.2 \%(\mathrm{w} / \mathrm{v})$ TAE-agarose gels. Analysis performance was unchanged from that obtained with denatured gel (data not shown).

\section{RESULTS AND DISCUSSION}

Isolated RNA yields with the MVC and C protocols were not significantly different, but the $\mathrm{A}_{260} / \mathrm{A}_{230}$ ratio indicated a significant difference in RNA purity (Table 1). The MVC protocol produced RNA free of polyphenols and carbohydrate contaminants $\left(\mathrm{A}_{260} / \mathrm{A}_{230}\right.$ ratios $>2$ ), while RNA using the $C$ protocol contained substantially higher contamination $\left(\mathrm{A}_{260} / \mathrm{A}_{230}\right.$ ratios $=0.55-0.63)$. Compared to these two protocols, the $\mathrm{VC}$ protocol produced less RNA but of significantly higher purity $\left(A_{260} / A_{230}\right.$ ratios $\left.=1.73-1.84\right)$ (Table 1$)$. Although the $A_{260} / A_{230}$ ratio results suggest that the MVC protocol was the most effective at removing phenols and carbohydrates from the RNA, this protocol's $\mathrm{A}_{260} / \mathrm{A}_{210}$ ratio (0.8) suggests the weak presence of other contaminants. However, the $C$ protocol produced RNA with a lower $A_{260} / A_{210}$ ratio (0.29), indicating a higher contaminant level, which is also supported by the $A_{260} / A_{230}$ ratio. The $\mathrm{A}_{260} / \mathrm{A}_{280}$ ratio is affected by acidic $\mathrm{pH}$ (Wilfinger, 1997; Okamoto and Okabe, 2000), and many manufacturer instructions for RNA extraction (Qiagen, Trizol, Omega Bio-tek, Stratagene) recommend the use of a buffered solution to dilute RNAs. Taking this into account, we compared the $\mathrm{A}_{260} / \mathrm{A}_{280}$ ratios of samples diluted with DEPC-treated water, $\mathrm{pH} 4.23$, or Tris$\mathrm{HCl}, \mathrm{pH}$ 7.5. Those diluted with DEPC-treated water apparently exhibited substantial protein contamination with the $\mathrm{VC}$ and $\mathrm{MVC}$ protocols, leading to RNA purity underestimation. This 
agrees with Okamoto and Okabe (2000), who reported that DEPC-treated water does not affect absorbance at $260 \mathrm{~nm}$ but does increase it at $280 \mathrm{~nm}$. This affects the $\mathrm{A}_{260} / \mathrm{A}_{280}$ ratio, producing underestimation of RNA quality.

Table 1. Comparison of means of absorbance ratios and total yields of RNA obtained from in vitro banana plantlet leaves using three extraction protocols.

\begin{tabular}{llllc}
\hline Method & $\mathrm{A}_{260210}$ & $\mathrm{~A}_{260 / 230}$ & $\mathrm{~A}_{260280}$ & RNA concentration $(\mu \mathrm{g} / \mathrm{g}$ fresh weight $)$ \\
\hline $\mathrm{VC}^{1}$ & $0.745^{\mathrm{c}}$ & $1.73833^{\mathrm{b}}$ & $1.96167^{\mathrm{bc}}$ & $127.038^{\mathrm{b}}$ \\
$\mathrm{MVC}^{1}$ & $0.882667^{\mathrm{a}}$ & $2.31^{\mathrm{a}}$ & $2.06167^{\mathrm{ab}}$ & $202.293^{\mathrm{a}}$ \\
$\mathrm{C}^{1}$ & $0.291667^{\mathrm{d}}$ & $0.63^{\mathrm{c}}$ & $1.91333^{\mathrm{c}}$ & $175.182^{\mathrm{ab}}$ \\
$\mathrm{VC}^{2}$ & $0.712167^{\mathrm{c}}$ & $1.84833^{\mathrm{b}}$ & $1.52167^{\mathrm{d}}$ & $129.193^{\mathrm{b}}$ \\
$\mathrm{MVC}^{\mathrm{b}}$ & $0.815167^{\mathrm{b}}$ & $2.3767^{\mathrm{a}}$ & $1.58^{\mathrm{a}}$ & $199.848^{\mathrm{a}}$ \\
$\mathrm{C}^{2}$ & $0.296667^{\mathrm{d}}$ & $0.553333^{\mathrm{c}}$ & $2.15833^{\mathrm{a}}$ & $203.897^{\mathrm{a}}$ \\
\hline $\mathrm{VC}$ & &
\end{tabular}

$\mathrm{VC}=$ small-scale Valderrama-Cháirez et al. protocol; $\mathrm{MVC}=$ modified small-scale Valderrama-Cháirez et al. protocol; $\mathrm{C}=$ Concert $^{\mathrm{TM}}$ Plant protocol. ${ }^{1} \mathrm{RNA}$ diluted with Tris-HCl, $\mathrm{pH}$ 7.4. ${ }^{2} \mathrm{RNA}$ diluted with DEPC-treated sterile distilled water. The same superscript letters within the same column indicate no significant difference $(\mathrm{P}=0.05)$ as determined by the Fisher least significant difference procedure.

On gels, the RNA samples exhibited two bright bands corresponding to $28 \mathrm{~S}$ and $18 \mathrm{~S}$ rRNA (Figure 1), with a ratio of intensities of 2:1, indicating a good-quality RNA with the VC and MVC protocols.

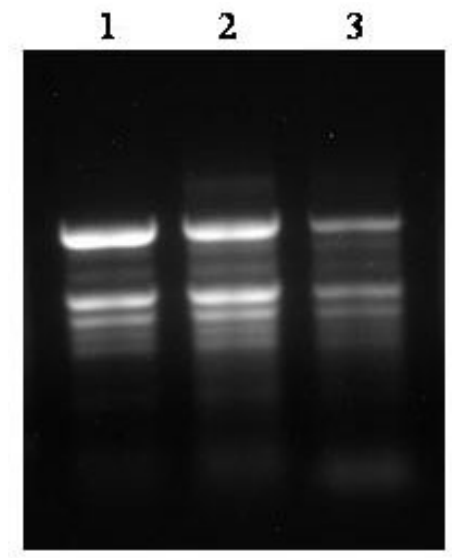

Figure 1. Total RNA extracted from in vitro banana plantlet leaves using three protocols: Lane $1=$ Small-scale Valderrama-Cháirez et al. protocol; lane 2 = modified small-scale Valderrama-Cháirez et al. protocol; lane $3=$ Concert $^{\mathrm{TM}}$ Plant RNA Reagent.

Because plant material represents the bulk of biological biomass in the pathogen-host interaction compared with $M$. fijiensis biomass, we evaluated the above RNA isolation protocols to determine which produced the highest quality and quantity of RNA in in vitro banana plantlet leaves. The MVC protocol produced the highest purity and yield of RNA and was used to extract total RNA from banana leaves artificially infected with $M$. fijiensis conidia harvested at 15 days post-inoculation. As expected, the protocol produced large amounts of high-quality total RNA (Figure 2). 


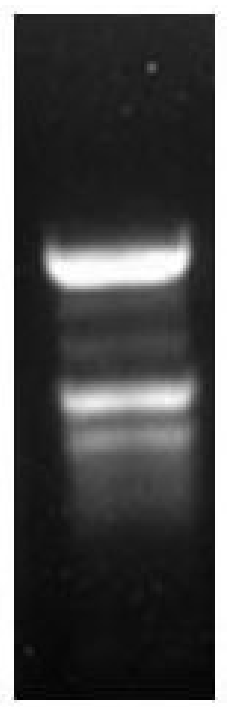

Figure 2. Total RNA extracted from in vitro Mycosphaerella fijiensi-infected banana plantlet leaves using the modified small-scale Valderrama-Cháirez et al. protocol.

The amplification of PCR products, $450 \mathrm{bp}$ for M. acuminata and $277 \mathrm{bp}$ for $M$. fijiensis, demonstrated that total RNA isolated with the MVC protocol was efficiently retrotranscribed into cDNA (Figure 3).
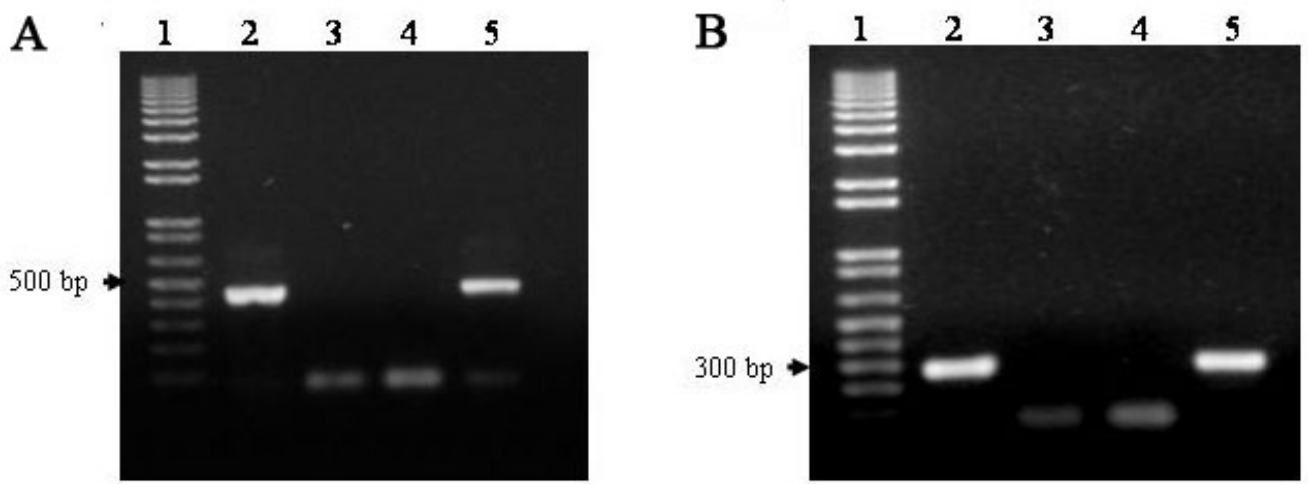

Figure 3. RT-PCR-amplified products using cDNA synthesized from total RNA extracted from in vitro banana plantlet leaves infected with conidia of Mycosphaerella fijiensis. Total RNA was extracted using the modified small-scale Valderrama-Cháirez et al. protocol. Lane 1 = 1-kb plus DNA ladder (Invitrogen) (A, B); A. Lane 2 $=\gamma$-actin fragment from banana; lane $3=$ negative control of lane 2 (sample without RT); lane $4=$ PCR control (water as template); lane $5=$ positive control, $\gamma$-actin fragment from $M$. acuminata gDNA. B. Lane $2=\gamma$-actin fragment from $M$. fijiensis; lane 3 = negative control of lane 2 (sample without RT); lane $4=$ PCR control (water as template); lane $5=$ positive control, $\gamma$-actin fragment from $M$. fijiensis gDNA. 
Sanchez-Rodríguez et al. (2008) reported an efficient method for isolating RNA, 48.67 $\pm 3.10 \mathrm{mg} / \mathrm{g}$, from M. fijiensis-infected banana leaves. Nevertheless, the modified ValderramaCháirez et al. protocol, which produced the highest yield $(202.293 \mathrm{mg} / \mathrm{g})$ and purity of RNA from in vitro banana leaves, improved substantially this result with a 4.1-fold increase in total RNA yield. Additionally, the MVC protocol reduced the processing time, lowered costs (minipreparation), and used less expensive equipment (bench-top centrifuge) compared to the method reported by Sanchez-Rodríguez et al. (2008). On the other hand, the Concert ${ }^{\mathrm{TM}}$ Plant protocol produced apparently good RNA yield (overestimated), and the RNA quality (purity and integrity) was the poorest for the three tested protocols, restricting its use for cDNA libraries and ESTs. In addition, measurement of RNA purity using a buffered solution such as Tris$\mathrm{HCl}, \mathrm{pH}$ 7.4, produced a more reliable $\mathrm{A}_{260} / \mathrm{A}_{280}$ ratio than with DEPC-treated water, $\mathrm{pH}$ 4.23. In conclusion, the highest yield and quality of RNA isolated from in vitro banana leaves were obtained with the modified Valderrama-Cháirez et al. protocol. Furthermore, this protocol reduced the processing time, lowered costs, used less expensive equipment, and could be used for other plants that have the same problems with high polyphenol and polysaccharide levels.

\section{ACKNOWLEDGMENTS}

Research supported by the Consejo Nacional de Ciencia y Tecnología (CONACYT, México) (grant \#58869). The authors wish to thank Adrian Enriquez for technical assistance.

\section{REFERENCES}

Louime C, Vasanthaiah HKN, Jittayasothorn Y, Lu J, et al. (2008). A simple and efficient protocol for high quality RNA extraction and cloning of chalcone synthase partial cds from muscadine grape cultivars (Vitis rotundifolia Michx.). Eur. J. Sci. Res. 22: 232-240.

MacRae E (2007). Methods in Molecular Biology. In: Protocols for Nucleic Acid Analysis by Nonradioactive Probes (Hilario E and Mackay J, eds.). Humana Press, Totowa, New Jersey, 15-24.

Manrique-Trujillo SM, Ramirez-Lopez AC, Ibarra-Laclette E and Gomez-Lim MA (2007). Identification of genes differentially expressed during ripening of banana. J. Plant Physiol. 164: 1037-1050.

Masek T, Vopalensky V, Suchomelova P and Pospisek M (2005). Denaturing RNA electrophoresis in TAE agarose gels. Anal. Biochem. 336: 46-50.

Mbéguié-A-Mbéguié D, Hubert O, Sabau X, Chillet M, et al. (2007). Use of suppression subtractive hybridization approach to identify genes differentially expressed during early banana fruit development undergoing changes in ethylene responsiveness. Plant Sci. 172: 1025-1036.

Montenegro BI, Oliveira OML, Hélio CJ, Arraes MG, et al. (2008). Isolation of total RNA from ripe and unripe soursop (Annona muricata L.) fruit. Afri. J. Plant Sci. 2: 94-98.

Okamoto T and Okabe S (2000). Ultraviolet absorbance at 260 and $280 \mathrm{~nm}$ in RNA measurement is dependent on measurement solution. Int. J. Mol. Med. 5: 657-659.

Paredes-López O, Del Villar-Martínez AA, Vanegas P, García-Saucedo P, et al. (2007). Biotechnology for flower development and pigment production in Tagetes erecta. Proceedings of the International Symposium on Biotechnology of Temperate Fruit Crops and Tropical Species (Litz RE and Scorza R, eds.). Acta Horticult. 738: 551-556.

Peraza-Echeverría L, Rodríguez-García CM and Zapata-Salazar DM (2008). A rapid, effective method for profuse in vitro conidial production of Mycosphaerella fijiensis. Australas. Plant Pathol. 37: 460-463.

Rodrigues SM, Soares VL, de Oliveira TM, Gesteira AS, et al. (2007). Isolation and purification of RNA from tissues rich in polyphenols, polysaccharides, and pigments of annatto (Bixa orellana L.). Mol. Biotechnol. 37: 220-224.

Rosas-Cárdenas F de F, Valderrama-Cháirez ML, Cruz-Hernández A and Paredes-López O (2007). Prickly pear polygalacturonase gene: cDNA cloning and transcript accumulation during ethylene treatment, cold storage and wounding. Postharvest Biol. Technol. 44: 254-259. 
Sánchez-Rodríguez A, Portal O, Rojas LE, Ocana B, et al. (2008). An efficient method for the extraction of high-quality fungal total RNA to study the Mycosphaerella fijiensis-Musa spp. interaction. Mol. Biotechnol. 40: 299-305. DOI 10.1007/s12033-008-9092-1.

Suzuki Y, Mae T and Makino A (2008). RNA extraction from various recalcitrant plant tissues with a cethyltrimethylammonium bromide-containing buffer followed by an acid guanidium thiocyanate-phenol-chloroform treatment. Biosci. Biotechnol. Biochem. 72: 1951-1953.

Valderrama-Cháirez ML, Cruz-Hernández A and Paredes-López O (2002). Isolation of functional RNA from cactus fruit. Plant Mol. Biol. Rep. 20: 279-286.

Van den Berg N, Crampton BG, Hein I, Birch PR, et al. (2004). High-throughput screening of suppression subtractive hybridization cDNA libraries using DNA microarray analysis. Biotechniques 37: 818-824.

Vasanthaiah HKN, Katam R and Sheikh MB (2008). Efficient protocol for isolation of functional RNA from different grape tissues rich in polyphenols and polysaccharides for gene expression studies. Electronic J. Biotech. 11: DOI: 10.2225/vol11-issue3-fulltext-5.

Wang X, Tian W and Li Y (2008). Development of an efficient protocol of RNA isolation from recalcitrant tree tissues. Mol. Biotechnol. 38: 57-64.

Wilfinger WW, Mackey K and Chomczynski P (1997). Effect of pH and ionic strength on the spectrophotometric assessment of nucleic acid purity. Biotechniques 22: 474-481.

$\mathrm{Xu}$ BY, Su W, Liu JH, Wang JB, et al. (2007). Differentially expressed cDNAs at the early stage of banana ripening identified by suppression subtractive hybridization and cDNA microarray. Planta 226: 529-539. 